Оригинални научни рад

Sanja V. Đajić, Ph.D., Full Professor

University of Novi Sad

Faculty of Law Novi Sad

S.Djajic@pf.uns.ac.rs

\title{
THE ACHMEA CASES - STORY ON TREATY INTERPRETATION, FORUM COMPETITION AND INTERNATIONAL LAW FRAGMENTATION ${ }^{1}$
}

\begin{abstract}
In this article the author examines decisions rendered by the UNCITRAL arbitral tribunal in an investment case Achmea v. Slovakia and judgment of the European Court of Justice regarding the compatibility of the investor-State dispute settlement provision in an intra-EU BIT with EU law relating the Achmea arbitral award on the merits. Given that the ECJ found incompatibility between the two such decision might have wide-ranging consequences. Here the author assesses arguments in different decisions from the perspective of fragmentation of international law, more precisely from the perspective of concepts and arguments developed within the International Law Commission Report on Fragmentation of International Law. While the fragmentation issue was discussed at the early stages of arbitral proceedings it was later abandoned and remained unmentioned by the ECJ. The cause of different takes on the relationship between dispute settlement provisions in intra-EU BIT and EU law could well be described not as a normative but rather as a conflict between different forums. Jurisdictional conflict thus gave rise to the problem of fragmentation in its strict sense-inability of a state to perform two treaty obligations simultaneously.
\end{abstract}

Keywords: Achmea, fragmentation, treaty interpretation, investment arbitration.

${ }^{1}$ The author gratefully acknowledges the support of the University of Novi Sad Faculty of Law Project Legal Tradition and New Challenges for Law. This article is the result of research conducted for this project under the individual research theme „Globalisation and Fragmentation of Contemporary International Law: International Law between Coherent System and Disintegration". 


\section{INTRODUCTION}

A recent decision of the European Court of Justice (ECJ) in Achmea case (2018) represents another stage in an ongoing debate on the relationship between EU law and international investment arbitration regarding intra-EU BITs. Achmea is not the only case where the issue of intra-EU BITs was raised but it is the case where the ECJ had the last and quite consequential word on applicability of arbitration clauses in intra-EU BITs. This article will not tackle all possible aspects of the Achmea case but will merely try to assess the arguments adopted by different international forums, such as the UNCITRAL investment tribunal and European Court of Justice, against the discussion on fragmentation of international law. This article will begin with the overview of relevant case law, starting from the two arbitral awards handed down by the UNCITRAL investment tribunal. The overview will chronologically follow the proceeding under Article 267 of the Treaty on the Functioning of the European Union (TFEU), which led to the decision of the European Court of Justice in 2018. These cases will then be assessed from the perspective of fragmentation of international law given that the development of this case is illustrative of inherent inconsistencies between different forums and most notably of the competition of different sub-systems of international law.

\section{BACKGROUND}

The European Court of Justice has recently handed down a decision in the Achmea case acting upon the request for a preliminary ruling submitted by the German Federal Court of Justice on the basis of Article 267 of the TFEU. ${ }^{2}$ The request was submitted in relation to the case between the Slovak Republic and Achmea BV concerning the UNCITRAL arbitral tribunal's award of 7 December $2012^{3}$ under the Agreement on encouragement and reciprocal protection of investments between the Kingdom of the Netherlands and the Czech and Slovak Federative Republic (hereinafter: "Dutch-Slovak BIT" or "BIT"). ${ }^{4}$ The ECJ ruled that provision of the applicable BIT, which provided for the jurisdiction of an arbitral tribunal to settle investment dispute between an EU national as an investor, and an EU Member State, on the basis of an intra-EU BIT is contrary to

${ }^{2}$ Slowakische Republic (Slovak Republic) v. Achmea BV, European Court of Justice, Case C-284/16, Judgment of the Court (Grand Chamber), 6 March 2018.

${ }^{3}$ Achmea B.V. v. The Slovak Republic, UNCITRAL, PCA Case No. 2008-13 (formerly Eureko B.V. v. The Slovak Republic), Final Award, 12 December 2012.

${ }^{4}$ The CSFR concluded Bilateral Agreement on the Promotion and Protection of Investments with The Netherlands, which was signed on 29 April 1991 and came into force on 1 October 1992. The Slovak Republic became an independent State on 1 January 1993. It succeeded to the CSFRNetherlands BIT as of the day of its independence. 
Articles 267 and 344 of the TFEU, which in turn preclude the operation of such BIT dispute settlement clause. This decision significantly affects similar provisions to be found in around 200 BITs in application between EU Member States. In other words, it could be argued that this decision might affect jurisdiction of potential arbitral tribunals constituted under intra-EU BIT. ${ }^{5}$ It could also be detrimental for the enforcement of such an arbitral award, at least within EU.

The background of this case is complex because it consists of the particular investment dispute that was launched by Eureko (subsequently changed to Achmea B.V.) against Slovak Republic on the ground that the host state breached several BIT guarantees granted to Dutch investors. In the course of the proceedings Slovakia raised several preliminary objections against the jurisdiction of the arbitral tribunal but to no avail. Interestingly, Slovakia also made an argument that subsequent treaties replace earlier treaties when they relate to the same subject-matter in the context of preventing fragmentation of international law. ${ }^{6}$ European Commission joined Slovakia arguing that by upholding its jurisdiction the arbitral tribunal would risk fragmentation of both international and EU law. ${ }^{7}$ This argument was easily dismissed by the arbitral tribunal.

Additional background to the Achmea case is a long ongoing debate about propriety of intra-EU BITs given that competence of the EU has been changed by Article 207 of the TFEU which transferred competence from the Member States to the EU regarding foreign direct investments and the protection of investments. With the entry into force of the Lisbon Treaty, the EU gained exclusive competence in respect of foreign direct investment as part of the common commercial policy (TFEU, Art. 207(1), Art. 3(1)(e)). ${ }^{8}$ In 2012 the European Parliament and

${ }^{5}$ For the contrary view, see Csongor István Nagy, "Intra-EU Bilateral Investment Treaties and EU Law After Achmea: 'Know Well What Leads You Forward and What Holds You Back'", German Law Journal 4/2018, 981-1015 ("The above considerations showcase that the Achmea ruling's scope is much narrower than the echo it is generating. Hence, although the CJEU's anti-arbitration attitude revealed itself, the status of intra-EU BITs is not fully settled." - Ibidem, at 996).

${ }^{6}$ Achmea B.V. v. The Slovak Republic, UNCITRAL, PCA Case No. 2008-13 (formerly Eureko B.V. v. The Slovak Republic), Award on Jurisdiction, Arbitrability and Suspension, 26 October 2010, para. 72 .

${ }^{7}$ Ibidem, paras. 185-186.

${ }^{8}$ Article 207 (ex Article 133 TEC)

1. The common commercial policy shall be based on uniform principles, particularly with regard to changes in tariff rates, the conclusion of tariff and trade agreements relating to trade in goods and services, and the commercial aspects of intellectual property, foreign direct investment, the achievement of uniformity in measures of liberalisation, export policy and measures to protect trade such as those to be taken in the event of dumping or subsidies. The common commercial policy shall be conducted in the context of the principles and objectives of the Union's external action.

Article 3

1. The Union shall have exclusive competence in the following areas:

(e) common commercial policy. 
the Council of European Union adopted the Regulation on establishing transitional arrangements for bilateral investment agreements between Member States and third countries, which, inter alia, states: "Following the entry into force of the Treaty of Lisbon, foreign direct investment is included in the list of matters falling under the common commercial policy. In accordance with Article 3(1)(e) of the Treaty on the Functioning of the European Union ('TFEU'), the European Union has exclusive competence with respect to the common commercial policy. Accordingly, only the Union may legislate and adopt legally binding acts within that area. The Member States are able to do so themselves only if so empowered by the Union, in accordance with Article 2(1) TFEU."9 In 2015 the European Commission initiated infringement proceedings against Austria, the Netherlands, Romania, Slovakia and Sweden asking them to terminate bilateral investment treaties between them. ${ }^{10}$ Following the Achmea decision "the Commission has intensified its dialogue with all Member States, calling on them to take action to terminate the intra-EU BITs, given their incontestable incompatibility with EU law."11

\section{EUREKO B.V. (ACHMEA B.V.) V. THE SLOVAK REPUBLIC $(\text { JURISDICTION })^{12}$}

Achmea (originally Eureko) is a Dutch private limited liability company engaged in providing financial services for a range of insurance products, including health insurance, pension products, asset management and banking. Claimant complained that various legislative measures introduced by the Respondent after a change in government in July 2006 constituted a systematic reversal of the 2004 liberalisation of the Slovak health insurance market that had prompted Eureko to invest in the Slovak Republic's health insurance sector. ${ }^{13}$ On 28 February 2008 Eureko had filed the complaint with the European Commission arguing that Slovakia's policies were contrary to basic EU law principles that had been a corner-

${ }^{9}$ Regulation (EU) No 1219/2012 of 12 December 2012, entered into force on 9 January 2013, Official Journal of the EU L 351/40, recital 1.

${ }^{10}$ Commission asks Member States to terminate their intra-EU bilateral investment treaties, European Commission - Press Release, 18 June 2015 (available at: http://europa.eu/rapid/ press-release_IP-15-5198_en.htm).

${ }^{11}$ Communication from the Commission to the European Parliament and the Council, $\operatorname{COM}(2018)$ 547, 19 July 2018, p. 2 (available at: https://eur-lex.europa.eu/legal-content/EN/TXT/ $\mathrm{PDF} /$ ?uri=CELEX:52018DC0547\& from=EN (15.9.2018.)).

12 Achmea B.V.v. The Slovak Republic, UNCITRAL, PCA Case No. 2008-13 (formerly Eureko B.V.v. The Slovak Republic), Award on Jurisdiction, Arbitrability and Suspension, 26 October 2010 (hereinafter: Achmea, Award on Jurisdiction).

${ }^{13}$ Ibidem, para. 7. 
stone of Eureko's confidence in investing in the Slovak Republic. ${ }^{14}$ European Commission launched an infringement procedure against the Slovak Republic under Article 226 of the EC Treaty that was pending at the time of rendering the award on jurisdiction.

On 1 October 2008 the Claimant initiated investment arbitration on the basis of Article 8 of the BIT. ${ }^{15}$ According to the Claimant the reversal of the liberalization measures led to several violations of the provisions of the Dutch-Slovak BIT. ${ }^{16}$ Slovakia responded with several objections challenging ratione personae and ratione materiae jurisdiction. Respondent also submitted the Intra-EU jurisdictional objection based on the Slovakia's membership in the EU.

By its Intra-EU jurisdictional objection Slovakia argued that Slovak Republic's membership in the EU deprives the Tribunal of jurisdiction because "(i) the European Community treaty ('EC Treaty') governs the same subject matter as the BIT and therefore the BIT should be considered terminated and/or inapplicable pursuant to Articles 59 and 30 of the Vienna Convention on the Law of Treaties ('VCLT' or 'Vienna Convention'), (ii) the arbitration clause in the BIT cannot apply because it is incompatible with the EC Treaty, as the ECJ has exclusive jurisdiction over Eureko's claims, and (iii) clauses such as Article 4 of the BIT relating to free transfer of capital have been held by the European Court of Justice ('ECJ') to be incompatible with EU law, which is supreme."' ${ }^{\prime 7}$ Tribunal invited European Commission and the Netherlands to submit their positions on the issue of intra-EU BITs. ${ }^{18}$ The Netherlands argued that the Dutch-Slovak BIT was still in force and that the tribunal

${ }^{14}$ Ibidem, para. 55.

${ }^{15}$ Relevant parts of Article 8 provide as follows:

(1) All disputes between one Contracting Party and an investor of the other Contracting Party concerning an investment of the latter shall if possible, be settled amicably.

(2) Each Contracting Party hereby consents to submit a dispute referred to in paragraph (1) of this Article, to an arbitral tribunal, if the dispute has not been settled amicably within a period of six months from the date either party to the dispute requested amicable settlement.

(3) ...

(5) The arbitration tribunal shall determine its own procedure applying the arbitration rules of the United Nations Commission for International Trade Law (UNCITRAL).

(6) The arbitral tribunal shall decide on the basis of the law, taking into account in particular though not exclusively:

- the law in force of the Contracting Party concerned;

- the provisions of this Agreement, and other relevant Agreements between the Contracting Parties;

- the provisions of special agreements relating to the investment;

- the general principles of international law.

${ }^{16}$ Claimant invoked the following substantive guarantees envisaged in the Dutch-Slovakia BIT: prohibition of expropriation, fair and equitable treatment, full protection and security, and free transfer of profits and dividends.

${ }^{17}$ Achmea, Award on Jurisdiction, para. 19 (references omitted).

${ }^{18}$ Ibidem, paras. 31, 34. 
had jurisdiction under Article 8 of the BIT. ${ }^{19}$ European Commission argued against intra-EU BITs as an "anomaly within the EU internal market" and challenged compatibility of such BITs with mandatory provisions of EU law and EU judicial system. ${ }^{20}$ The arguments of the European Commission were complex and invariably against intra-EU BITs. Such agreements were designated as incompatible with EU legal system, which rests on the principles of autonomy and supremacy of EU law. Supremacy of EU law requires the compatibility of all Member States international agreements with EU treaties. The principle of supremacy of EU law thereby replaced the principle of pacta sunt servanda for intra-EU international agreements. ${ }^{21}$ The Commission challenged the propriety of intra-EU BITs on the basis of potential discrimination between EU investors from different Member States, also incompatible with EU law. ${ }^{22}$ Finally, the European Commission argued that resort to outside dispute settlement mechanism would "inevitably promote competing judicial and arbitral mechanisms, increase 'forum shopping' by litigants and contribute to the risk of further fragmentation of international law." ${ }^{23}$ Policy reasons against BIT arbitration are that they enhance mistrust in the courts of EU Member States and administration of justice in the European Union. While the Commission argued that Article 59 of the VCLT did not terminate the Dutch-Slovak BIT ${ }^{24}$ it nevertheless found that certain provisions of the BIT had become inapplicable due to operation of Article 30 of the VCLT, including Article 8 which sets forth investor-State arbitral mechanism..$^{25}$ The European Commission also warned about the practical consequences of the fragmentation given the pending infringement proceeding before the ECJ which could potentially reach a different conclusion. It suggested that arbitral tribunal should stay the proceeding (like the ITLOS tribunal did in the MOX Plant case) until the adoption of the final decision by the ECJ. ${ }^{26}$

The tribunal rejected all objections lodged by Slovakia and all arguments submitted by the European Commission. The first task for the tribunal was to solve the interplay between international and EU law. Applicability of international law, and thereby of the Vienna Convention on the Law of Treaties, was beyond doubt. As for the EU law the tribunal first designated it as a part of German law, applicable as the lex loci arbitri under UNCITRAL rules because the agreed place of arbitration was Frankfurt in the Federal Republic of Germany. ${ }^{27}$ In the opinion

${ }^{19}$ Ibidem, para. 161.

${ }^{20}$ Ibidem, paras. 177-179.

${ }^{21}$ Ibidem, paras. 179-182.

22 Ibidem, paras. 183-184.

${ }^{23}$ Ibidem, para. 185.

${ }^{24}$ Ibidem, para. 187.

${ }^{25}$ Ibidem, para. 193.

${ }^{26}$ Ibidem, paras. 194-196.

${ }^{27}$ Article 16 of the UNCITRAL Arbitration Rules and $\S 1043$ of the German Arbitration Law, the Tenth Book of the German Code of Civil Procedure. See, ibidem, para. 224. 
of the tribunal it was a German arbitration subject to German laws. Therefore, primary rules are international as they are first to be applied in assessing the consent of the parties, whereas EU law comes as secondary in order to check whether such consent can be qualified or circumscribed by operation of legal provisions that lie outside the text of the BIT. ${ }^{28}$ The conclusion was that the relevant legal framework for jurisdiction included BIT, international law and EU law. Later in the course of discussion on applicable law the tribunal noted that Article 8(6) of the BIT allowed for inclusion of EU law as "the law in force of the Contracting Party concerned" and as "other relevant Agreements between the Contracting Parties" and as part of "the general principles of international law". ${ }^{29}$

The tribunal rejected the submission that the BIT had been automatically terminated in accordance with the rules set out in the VCLT Article 59, mainly because there was no notification of termination as required by Article 65 of the VCLT, but also because Article 59 of the VCLT applies when there are successive treaties "relating to the same subject-matter." ${ }^{30}$ Given that Article 59 leads to the termination of the entire treaty the degree of overlapping must be substantial and the tribunal did not find that the required level of incompatibility between the BIT and EU law existed, nor that there was a "clear intention that the BIT should be terminated by any of the CSFR Association Agreement, the Association Agreement, the Accession Treaty or the Lisbon Treaty." 31 There was no evidence demonstrating the will to terminate the BIT by operation of the EU law. As regard to the substantive compatibility of the protection guaranteed by the BIT and the protection provided for by EU law, the tribunal could not find sufficient identity between the two:

"Thus, EU law does not provide substantive rights for investors that extend as far as those provided by the BIT. There are rights that may be asserted under the BIT that are not secured by EU law.... Nor can it be said that the provisions of the BIT are incompatible with EU law. The rights to fair and equitable treatment, to full protection and security, and to protection against expropriation at least, extend beyond the protections afforded by EU law; and there is no reason why those rights should not be fulfilled and upheld in addition to the rights protected by EU law." 32

${ }^{28}$ Achmea, Award on Jurisdiction, para. 226.

${ }^{29}$ Ibidem, para. 289.

${ }^{30}$ Article 59 of the VCLT, as an argument against jurisdiction of a BIT-based arbitration as incompatible with EU membership, was used in previous investment cases and in none of them was successful. See, Eastern Sugar BV v. Czech Republic, SCC Case 088/2004, Partial Award, 27 March 2007.

${ }^{31}$ Achmea, Award on Jurisdiction, para. 244.

${ }^{32}$ Ibidem, paras. 262-263. 
An additional and essential difference in investment protection favouring BITs the tribunal derived from the procedural advantage of an investor to initiate UNCITRAL proceeding against the State which, in the opinion of the tribunal, could not "be equated simply with the legal right to bring legal proceedings before the national courts of the host state; and, moreover, the locus standi of an investor under the BIT, with its broad definition of 'indirect' investments under Article 1, is unlikely to be replicated under the court procedures of an EU Member State. ${ }^{\text {333 }}$

Second objection based on Article 30 of the VCLT was dismissed along the similar lines given that incompatibility was not present to the extent to render Article 8 of the BIT inapplicable. The tribunal offered two additional explanations: any incompatibility would be assessed on the basis of applicable law which leaves the matter for the merits and not for jurisdiction. ${ }^{34}$ The second was that "no rule of EU law prohibits investor-State arbitration." 35

The third objection was based on the argument that EU law should prevail over international agreements but also that only the European Court of Justice has exclusive competence to interpret EU law. The tribunal rejected this objection on the ground that it belongs to the merits stage but it did open the discussion on possibilities of being deprived of jurisdiction on the basis of EU law:

"The only basis - beyond the arguments already discussed in relation to VCLT Articles 30 and 59- on which the Tribunal might arguably be deprived of jurisdiction on the basis of the status of EU law is that the Tribunal needs to consider and apply EU law in order to decide the present case and yet is entirely precluded from considering and applying any such EU law by the Parties' consent derived from Article 8 of the BIT or German law." 36

However, the tribunal rejected this proposition on the ground that it might not be precluded from applying EU law. ${ }^{37}$ It concluded, at this stage, that it can apply EU law both as a matter of international and as a matter of German law, and thereby possibly EU law doctrines "including those of supremacy, precedence, direct effect, direct applicability". 38

${ }^{33}$ Ibidem, para. 264.

${ }^{34}$ Ibidem, para. 273.

35 Ibidem, para. 274.

${ }^{36}$ Ibidem, para. 280.

37 "The argument that the ECJ has an 'interpretative monopoly' and that the Tribunal therefore cannot consider and apply EU law, is incorrect. The ECJ has no such monopoly. Courts and arbitration tribunals throughout the EU interpret and apply EU law daily. What the ECJ has is a monopoly on the final and authoritative interpretation of EU law: but that is quite different. Moreover, even final courts are not obliged to refer questions of the interpretation of EU law to the ECJ in all cases. The acte clair doctrine is well-established in EU law." - Ibidem, para. 282.

${ }^{38}$ Ibidem, para. 289. 


\section{ACHMEA B.V. (EUREKO B.V.) V. THE SLOVAK REPUBLIC $(\text { MERITS })^{39}$}

On the merits the arbitral tribunal found Slovakia responsible for the breach of its obligations under the Dutch-Slovak BIT and ordered Slovakia to pay over EUR 22 million in damages and over EUR 3 million in costs to Achmea. During the proceedings on the merits the Respondent raised again the problem of interaction of the BIT with the substantive provisions of the EU law. The argument was that "the subject matter of the dispute is governed by the EU law" so the tribunal does not have jurisdiction given the lack of instructions on particular issues (such as whether restrictions on the distribution of profits from public health insurance would be in breach of EU law, etc.)..$^{40}$ The tribunal summarily rejected this argument finding that intra-EU objection was dismissed in its preliminary award on jurisdiction which is of res judicata character and binding upon the parties. In other words, the tribunal did not revert to the applicability of EU law as a jurisdictional issue. However, it did revert to the applicability of EU law within the discussion on liability, as promised in its Award on Jurisdiction. ${ }^{41}$ The tribunal without much difficulty dismissed any dilemma having found that there existed strict division of EU law and BIT in the dispute at hand:

"In the present case, the Treaty sets out standards of treatment that the Contracting Parties have expressly agreed to apply to investors of the other Contracting Party. Insofar as they are applicable to the facts in the present case, nothing in those Treaty standards is in conflict with any provision of EU law. Nothing in this Award amounts to, or implies, a decision that Respondent or Claimant has acted in conformity with EU law or contrary to EU law in any respect. This Award has no bearing upon any question of EU law. This Award relates only to the compliance by Respondent with the terms of the obligations it has assumed under the agreement that it made in the Treaty in relation to its treatment of a class of persons of which Claimant is a member;"'42

While it may be argued that the tribunal did not foreclose the applicability of EU law as a matter of principle, the facts of the cases did come as close as possible both to the application of EU law and to the conflict with the ECJ given both the infringement procedure and exclusive jurisdiction of the ECJ to have final say on interpretation of EU law.

${ }^{39}$ Achmea B.V. v. The Slovak Republic, UNCITRAL, PCA Case No. 2008-13 (formerly Eureko B.V. v. The Slovak Republic), Final Award, 12 December 2012 (hereinafter: Achmea, Final Award).

${ }^{40}$ Ibidem, para. 149.

${ }^{41}$ Achmea, Award on Jurisdiction, paras. 287-290.

42 Achmea, Final Award, para. 276. 


\section{SLOWAKISCHE REPUBLIC (SLOVAK REPUBLIC) V. ACHMEA BV, EUROPEAN COURT OF JUSTICE ${ }^{43}$}

Following the arbitral award of 7 December 2012 Slovakia brought an action to set aside the award before the High Regional Court in Frankfurt am Main in Germany. ${ }^{44}$ The action was dismissed and Slovakia appealed on a point of law before the Federal Court of Justice, which stayed the proceeding and referred the question to the European Court of Justice for a preliminary ruling on the basis of Article 267 of the TFEU. The referring court noted that the 1991 BIT "constituted an agreement between Member States, so that in the event of conflict the provisions of EU law take precedence, in the matters governed by them, over the provisions of the BIT." 45 The questions referred to the ECJ were whether arbitration clause in an intra-EU BIT, which provides for an investor-state arbitration between a national of one Member State and another Member State for investment disputes arising under such intra-EU BIT, was precluded by Articles 18(1), 267 and 344 of the TFEU. ${ }^{46}$ Advocate General, in his Opinion, argued that there was no incompatibility between the TFEU and investor-State dispute settlement clauses in intra-EU BITs. ${ }^{47}$

As many as 15 states submitted written observations. Majority of states, who had been more often than others respondents in investment cases under intra-EU BITs, ${ }^{48}$ sided with Slovakia. As observed by the Advocate General: "Faced with such economic reality, it is hardly surprising that the Member States in the second group have intervened in support of the argument put forward by the Slovak Republic, which is itself the respondent to the investment arbitration at issue in the present case. ${ }^{\text {449 }}$ However, as also noted by the Advocate General, none of these states, except Italy, denounced intra-EU BITs. ${ }^{50}$

The ECJ responded to questions arising under Articles 267 and 344 of the TFEU simultaneously. Having relied on the principle of the autonomy and primacy of the EU legal order, and exclusive jurisdiction of the ECJ for all disputes as between Member States concerning the interpretation or application of the Treaties,

${ }^{43}$ Case C-284/16, Judgment of the Court (Grand Chamber), 6 March 2018.

${ }^{44}$ Slovakia brought an action to set aside the 2010 Award on Jurisdiction before German courts but it was not successful (Ibidem, para. 11) It seems that no request for preliminary ruling was initiated by German courts on the basis of Article 267 of the TFEU in this case.

${ }^{45}$ Case C-284/16, op. cit., para. 13.

${ }^{46}$ Ibidem, para. 23.

${ }^{47}$ Opinion of Advocate General Wathelet, delivered on 19 September 2017, Case C-284/16, Slowakische Republik v Achmea BV.

${ }^{48}$ For example, as of October 2017, Spain was respondent in 33 cases under intra-EU BITs, Czech Republic in 26 cases, Hungary and Poland in eleven cases. See, ibidem, para. 35.

${ }^{49}$ Case C-284/16, op. cit., para. 36.

${ }^{50}$ Ibidem, paras. 37-38. Even Italy did not denounce all of its intra-EU BITs leaving the one with Malta in force. Also, all EU Member States are parties to the Energy Charter Treaty. 
the Court first proceeded to examine whether an arbitral tribunal, such as the one established under Article 8 of the Dutch-Slovak BIT, could be considered a court or tribunal of a Member State within the meaning of Article 267 of the TFEU. The answer was negative which meant that such arbitral tribunal was not entitled to make a reference to the ECJ for a preliminary ruling. ${ }^{51}$ ECJ further noted that commercial and investment arbitrations are different ${ }^{52}$ to the extent that Article 19(1) of the TEU cannot be applied in relation to the latter which leaves investment decisions outside the scope of judicial system of the EU, which in turn prevents investor-state disputes "from being resolved in a manner that ensures the full effectiveness of EU law, even though they might concern the interpretation or application of that law"53. The ECJ came to this conclusion despite the fact that Achmea tribunal did not in effect apply EU law. While the arbitral tribunal did say that it was competent to apply EU law as part of applicable law under the BIT it nevertheless declined to do so. Despite the fact that in this particular case the autonomy or even supremacy of EU law was not in danger, the ECJ still denied the right to Article 8 of the BIT to exist: "Article 8 of the BIT is such as to call into question not only the principle of mutual trust between the Member States but also the preservation of the particular nature of the law established by the Treaties." ${ }^{54}$ Consequently, the ECJ found that Article 8 of the BIT had an adverse effect on the autonomy of EU law. ${ }^{55}$ The final decision of the ECJ was that Articles 267 and 344 of the TFEU must be interpreted as precluding a provision in an international agreement concluded between Member States, such as Article 8 of the Dutch-Slovakia BIT.

\section{FRAGMENTATION DISCOURSE}

Fragmentation of international law as such was not at the heart of the Achmea problem either before the UNCITRAL arbitral tribunal or before the ECJ. Still, much of the arguments raised by the parties and by the courts laid bare anxieties

${ }^{51}$ Case C-284/16, op. cit., para. 49.

52 This alleged difference made by the ECJ was strongly criticized by commentators: "The above distinction - commercial arbitration is based on party autonomy, while investment arbitration on a treaty - is difficult to conceive. The treaty is based on the party autonomy of two sovereigns, and by the use of its dispute settlement mechanism the investor accepts it. It is painfully difficult to argue that arbitration between a state and an investor is not based on the 'freely expressed wishes of the parties.' The second circumstance referred to in the above excerpt may cause a similar headache: Commercial and investment arbitration may equally involve the application of EU law, let alone that investment arbitral tribunals quite often encounter purely contractual disputes, which could equally be subject to commercial arbitration." - Nagy, 992.

${ }^{53}$ Case C-284/16, op. cit., para. 56.

${ }^{54}$ Ibidem, para. 58.

${ }^{55}$ Ibidem, para. 59. 
within international legal system as well as fragmentation on both normative and jurisdictional level. Against the background of the ILC's seminal Report on Fragmentation, ${ }^{56}$ fragmentation can be assessed from different angles. Given that the investment tribunal discussed the application of Articles 30 and 59 of the Vienna Convention on the Law of Treaties regarding the relationship between obligations arising under the BIT and EU law, it follows that it was the identity or proximity of a subject-matter of different treaties that potentially created normative conflict. This opened up the discussion about fragmentation through the emergence of a special law as an exception to the general law thereby causing fragmentation as differentiation between types of special law. ${ }^{57}$ Regardless of the general rules of international law and "a strong presumption against normative conflict" 58 favouring harmonization and systemic integration, here we have the discussion of two different sub-systems and possibly of two self-contained regimes. Despite the fact that two different sets of international rules are to be reconciled by reference to general international law, ${ }^{59}$ much of it depends, as these cases demonstrate, on jurisdiction of the forum which will resolve such normative conflict. Thus this becomes less the relationship between general and special legal norms, or between special sets of norms, simply due to the jurisdiction of the courts involved where each court has strong incentive for self-preservation which is mixed with a presumed duty to avoid conflicts with general rules of international law. This opposition, or fragmentation, materialized not only because of the possible normative conflict between the two different sets of rules, but equally because these conflicts were assessed by forums each belonging to the legal framework that gave rise to the initial normative conflict.

\section{Normative conflict between international investment law and EU law}

The problem of normative conflict has been in focus of international scholarship for a long time before the International Law Commission tackled the issue in its Report on Fragmentation. The problem has seen different articulations: as

${ }^{56}$ International Law Commission, Fragmentation of International Law: Difficulties Arising from the Diversification and Expansion of International Law, Report of the Study Group of the International Law Commission, UN Doc. A/CN.4/L.682, 13 April 2006.

${ }^{57}$ Ibidem, at 30-31, 33-34.

${ }^{58}$ Ibidem, para. 37.

${ }^{59}$ Rodoljub Etinski, "Means Of Interpretation of International Treaties and Determinants of Their Significance", Collected Papers of the Faculty of Law University of Novi Sad (Zbornik radova Pravnog fakulteta $u$ Novom Sadu) 4/2017, 603-624.

Sanja Djajić, "Mapping The Good Faith Principle in International Investment Arbitration: Assessment of Its Substantive and Procedural Value", Collected Papers of the Faculty of Law University of Novi Sad (Zbornik radova Pravnog fakulteta u Novom Sadu) 3/2012, 207-233. 
conflicts and mere divergences ${ }^{60}$ as conflicts between permissive and prescriptive norms, ${ }^{61}$ conflicts between different law-making treaties, ${ }^{62}$ conflicts as strict or loose incompatibility, ${ }^{63}$ etc. According to Jenks direct incompatibility in the strict sense arises "where a party to the two treaties cannot simultaneously comply with its obligations under both treaties." ${ }^{\text {"64 }}$ While a variety of remedies were detected in the Report on Fragmentation and in literature, there are two that might be apposite for the Achmea discussion. The first is the resolution through the general rules of international law such as the application of lex specialis or lex posterior principles or through the rules of Articles 30 and 59 of the VCLT for resolving the conflicts arising under successive treaties. These are the rules of general international law that serve precisely this purpose to resolve normative conflicts. However, there have been other suggestions in relation to the conflict between different treaty regimes: differences that exist between law-making treaties due to their complex origins, norm structures and dispute settlement mechanism may call for application of analogy with conflict of laws rules. ${ }^{65}$ Therefore, in order to solve the conflict one needs to look for conflicts of laws regulations within treaty regimes ${ }^{66}$ i.e. for special conflict of laws rules.

In the course of arbitral proceeding the main argument raised by Slovakia was the one of the normative conflict between international investment law and EU law. In Slovakia's opinion such normative conflict led to termination or at least to inapplicability of the BIT as a whole or alternatively of its Article 8. In order to illustrate the overlapping between the guarantees in the BIT and guarantees provided for in the EU law to foreign investors, Slovakia offered an overview of parallelism of guarantees. The purpose was two-fold: to prove the identity of subject-matter of two different treaties as a prerequisite for application of Articles 30 and 59 of the VCLT, and to prove that EU law provides guarantees to investors to the same extent as the BIT. The Achmea tribunal did not find that there was a conflict that would warrant the termination. ${ }^{67}$ Indeed, the overlap between EU law and BIT was not mutually exclusive but rather a matter of convergence. This

${ }^{60}$ Wilfred Jenks, 'Conflict of Law-Making Treaties', British Yearbook of International Law, 1953, 401-453, at 425-427.

${ }^{61}$ Erich Vranes, "The Definition of 'Norm Conflict' in International Law and Legal Theory”, European Journal of International Law, 2/2006, 395-418.

62 Jenks, 425-427.

${ }^{63}$ Report on Fragmentation, op. cit., para. 24.

${ }^{64}$ Jenks, 426.

${ }^{65}$ Jenks, 403.

${ }^{66}$ Tobias Lock, The European Court of Justice and International Courts, Oxford 2015, 40.

67 "Moreover, the BIT establishes extensive legal rights and duties that are neither duplicated in EU law nor incompatible with EU law. The protections afforded to investors by the BIT are, at least potentially, broader than those available under EU law (or, indeed, under the laws of any EU Member State)." - Achmea, Award on Jurisdiction, para. 254. 
habitual convergence could be seen as a natural result of the fact that they are addressing different subject-matters. ${ }^{68}$ Therefore, not every overlap can produce conflict that affects the applicability or validity of an international instrument, but sometimes the overlapping can induce fragmentation.

There was another normative conflict in the Achmea case that seemed to have been more fundamental for the general issue of interaction between intra-EU BITs as part of international investment law, on one hand, and as part of EU law, on the other. EU law requires that all treaties between Member States must conform with obligations arising under EU Treaties. General international law (apart from Article 103 of the UN Charter and jus cogens norms), makes no reference to any hierarchy as between treaties. Hence, apriori precedence of EU law over intra-EU BITs is difficult to accommodate under general rules of international law. However, this supremacy rule can be seen as a conflict of laws rule envisaged for resolution of different treaty regimes. ${ }^{69}$ Therefore, rules on how to resolve conflicts between different treaty obligations are fundamentally different depending on the legal order that is in position to resolve the conflict.

There was another normative conflict looming large behind the Achmea case before the ECJ. A year after the Achmea arbitral award on the merits was delivered, another investment tribunal handed down arbitral award on the basis of Romania-Sweden BIT, another intra-EU BIT. In the Micula $v$ Romania case $^{70}$ the tribunal awarded damages to the claimant for the breach of fair and equitable treatment that was caused by the Romania's withdrawal of certain investment incentives, such as tax and customs duties exemptions. Romania argued, and the European Commission confirmed, that this revocation was mandatory in the course of Romania's accession to the European Union. The tribunal rejected this defence and found that the claimant's legitimate expectations that such incentives would stay in place for the period of ten years, as guaranteed by the revoked legislation, were breached. The follow-up is quite telling about the relationship between the EU institutions and investment arbitration set up under the intra-EU BITs. European Commission practically banned the enforcement of the award with the argument that such enforcement would constitute a state aid incompatible with the

${ }^{68}$ August Reinisch, "Articles 30 and 59 o fthe Vienna Convention on the Law of Treaties in Action: The Decisions on Jurisdiction in the Eastern Sugar and Eureko Investment Arbitrations", Legal Issues of Economic Integration, 1/2012, 157-177, at 168.

69 "The Commission asserts that where there is a conflict with EU law, the rule of pacta sunt servanda does not apply to agreements between EU Member States, because of the jurisprudence establishing that 'EU law takes supremacy not only over the national legal systems, but also over bilateral agreements concluded between Member States'." - Ibidem, para. 180.

${ }^{70}$ Ioan Micula, Viorel Micula, S.C. European Food S.A, S.C. Starmill S.R.L. and S.C. Multipack S.R.L. v. Romania, ICSID Case No. ARB/05/20, Award, 11 December 2013. 
internal market within the meaning of Article 107(1) of the TFEU..$^{71}$ While Romania was banned to allow the enforcement of the award as a matter of EU law, this did not prevent claimants to search for other avenues to enforce the award. ${ }^{72}$ Micula case vividly illustrates the issue of treaty conflict due to incompatibility of obligations of Romania under two different treaties, TFEU (Article 107) and the ICSID Convention (Articles 54-55). The similar prospect was imminent in Achmea case given that any award on damages could be in conflict with prohibition of state aid. This conflict perfectly fits the concept of direct incompatibility in the strict sense as seen by the ILC Draft Articles on Fragmentation:

"A strict notion would presume that conflict exists if it is possible for a party to two treaties to comply with one rule only by thereby failing to comply with another rule. This is the basic situation of incompatibility. An obligation may be fulfilled only by thereby failing to fulfil another obligation."73

In final stages of the Achmea saga, both before the investment tribunal and the ECJ, there was no attempt to employ the strategy of systemic integration. While the Achmea tribunal did resort to the VCLT during the jurisdictional stage of the proceeding it fully abandoned reference to general international law during the merits stage. The ECJ never approached the issue from the standpoint of general international law, the position the European Commission held before the investment tribunal, but from the position that principles of supremacy and autonomy of EU law order were the criteria for settling fragmentation. The normative conflict may have just turned into a normative war, ${ }^{74}$ or more precisely into a jurisdictional war.

\section{Jurisdictional conflict between investment tribunals and ECJ}

The existing treaty conflict was not alleviated by the fact that two different jurisdictional clauses empowered different international courts to assess the matter.

${ }^{71}$ For an extensive overview of the measures employed by the European Commission following the award in the Micula v Romania case, see Maja Stanivuković, "Legitimate Expectations: A Commentary of Micula v. Romania”, 14 Transnational Dispute Management, 1/2017.

${ }^{72}$ Micula brothers sought the annulment of the 2015 Commission's decision before the ECJ - European Food and Others v. Commission, Case T-624/15, Action submitted on 6 November 2015, OJ C 16, 18 January 2016, 45-46 (case is still pending). Micula brothers are still seeking enforcement before US and UK courts. See, Tom Jones, "Romania undoes enforcement of Micula award", Global Arbitration Review, 24 October 2017, available at: https://globalarbitrationreview. com/article/1149309/romania-undoes-enforcement-of-micula-award (23 September 2018); Viorel Micula and others $v$ Romania and European Commission (Intervener), Court of Appeal, UK, [2018] EWCA Civ 1801Case No: A3/2017/1853, 1855, 1856 \& 1903, 27 July 2018.

${ }^{73}$ Report on Fragmentation, para. 24.

${ }^{74}$ For a critical overview of maximalist and polemical approach of actors involved in the discussion on the relationship between EU law and intra-EU BITs, see Panos Koutrakos, "The Relevance of EU Law for Arbitral Tribunals: (Not) Managing the Lingering Tension", Journal of World Investment \& Trade, 6/2016, 873-894. 
Such situations have been termed as a "parallelism of treaties, both in their substantive content and in their provisions for settlement disputes arising thereunder." 75 Had it been only one judicial body in place the treaty conflict would have been solved more easily, or perhaps would have remained merely unnoticed. It is not only the substantive law on which the resolution depends but resolution equally depends on the forum (and its jurisdiction) which will have the say in resolving the conflict. The resolution equally hinges on the substantive law and on the forum (and its jurisdiction) which will have the say in resolving the conflict:

"What is more, where a conflict between a BIT and EU law exists, the European courts and institutions must be expected to assess the consequences of such a conflict from a perspective that is different from the perspective of an arbitral tribunal. An arbitral tribunal will first and foremost apply the treaty invoked by the investor, and any conflicts between the norms contained in that treaty and the European treaties will have to be resolved in accordance with the relevant principles of international law. In particular, from the perspective of a treaty-based tribunal, EU law can only be relevant to the extent where international law so provides." 76

In cases of jurisdictional conflicts when different tribunals are empowered to assess the conflict it is very likely that such tribunals will rather employ their own conflict of laws rules than rules of general international law. However, there are examples to the contrary. In the Mox Plant case the arbitral tribunal set up under Annex VII of the UNCLOS Convention provisionally suspended proceedings because there was "a real possibility that the European Court of Justice may be seised of the question whether the provisions of the 1982 Convention on which Ireland relies are matters relating to which competence has been transferred to the EC, and indeed that issues concerning the interpretation and application of the provisions of the Convention are as such matters of EC law. In these circumstances, whether, and if so to what extent, all or any provisions of the 1982 Convention fall within the competence of the EC or its Member States would fall to be decided by the European Court of Justice." 77 Suspension of the procedure was due to the tribunal's deference to the ECJ jurisdiction despite the fact the European Commission did not intervene in the matter as it did in the Achmea arbitration. There was nothing in the instrument providing for jurisdiction of the Annex VII arbitral

\footnotetext{
${ }^{75}$ Southern Bluefin Tuna Case Australia and New Zealand v. Japan, Award on Jurisdiction and Admissibility, August 4, 2000 rendered by the Arbitral Tribunal constituted under Annex VII of the United Nations Convention on the Law of the Sea, para. 52. Available at: http://legal.un.org/ riaa/cases/vol_XXIII/1-57.pdf (accessed: 20 September 2018).

${ }^{76}$ Hanno Wehland, "The Enforcement of Intra-EU BIT Awards: Micula v Romania and Beyond", The Journal of World Investment \& Trade, 6/2016, 942-963, at 943 (references omitted).

${ }^{77}$ MOX Plant Case (Ireland v. United Kingdom), PCA Case no. 2002-01, President's Statement of June 13, 2003, para. 8.
} 
tribunal in the Mox case which mandated suspension of the proceeding so it rather seems that the arbitral tribunal relied on international comity considerations. ${ }^{78}$ The arbitral tribunal anticipated well the events that would unfold before the ECJ. Following the decision on suspension before the arbitral tribunal the European Commission instituted proceedings against Ireland for the breach of Article 292 of the EC Treaty. The Court in Luxembourg upheld the claim ${ }^{79}$ and confirmed its exclusive jurisdiction in the matter. ${ }^{80}$ The Annex VII arbitral tribunal extended the suspension until Ireland formally discontinued the arbitral proceeding.

Going back to Achmea, it was the jurisdictional conflict that was seen as crucial for finding that arbitration clause in Article 8 of the Dutch-Slovak BIT (and potentially similar provisions in other intra-EU BITs) was contrary to EU law and as such inapplicable. Opinion of the European Commission and decision of the ECJ, perhaps not surprisingly, were in favour of the ECJ jurisdiction to the exclusion of any other remedy available to investors protected under the intra-EU BITs. The special feature of the legal nature of the EU law was seen closely connected to the exclusive jurisdiction of the ECJ which always retains the power to have the final say on EU law matters. Given that there is no mechanism that could make investment tribunal refer to the ECJ for a preliminary ruling, absence of such mechanism was seen as incompatible with Articles 267 and 344 of the TFEU. It is not hard to see that other international courts would be in a difficult position to follow the ECJ in its ruling, not only for obvious reasons, such as inability to fully embrace the idea of exclusive jurisdiction of the ECJ but simply because they would not be guided by the same conflict of laws rules. While for the ECJ it is the primacy of founding treaties over any other treaties signed between Member States, for other international courts this would not be so much about hierarchy as much about the successive treaties relating to the same subject-matter. Therefore, it would not be far-fetched to assume that other international courts would follow in the footsteps of the Achmea arbitral tribunal and its discussion on the applicability of Articles 30 and 59 of the VCLT.

78 "The Tribunal considers that a situation in which there might be two conflicting decisions on the same issues would not be helpful to the resolution of this international dispute. Nor would such a situation be in accord with the dictates of mutual respect and comity that should exist between judicial institutions deciding on rights and obligations as between States, and entrusted with the function of assisting States in the peaceful settlement of disputes between them." - MOX Plant Case (Ireland v. United Kingdom), PCA Case no. 2002-01, President's Statement of June 13, 2003, para. 11

${ }^{79}$ Case C-459/03, Commission v Ireland, Judgment of the Court (Grand Chamber) of 30 May 2006.

${ }^{80}$ Nikolaos Lavranos, "Protecting Its Exclusive Juisdiction: The Mox Plant-Judgment of the ECJ", The Law and Practice of International Courts and Tribunals, 5/2006, 479-493. 


\section{CONCLUSION}

Much of the arguments heard in different Achmea litigations echo the anxieties inherent in fragmentation of international law on both normative and jurisdictional levels. While the cases did not disclose the real normative conflict between different treaties so strict to mutually exclude different treaty regimes, it seems that the animosity was rather generated by the maximalist approaches of different forums to reading its jurisdictional authority. There seem to be simultaneous causes and sources of fragmentation, leading to different remedies coming from different authorities.

Normative and jurisdictional overlapping tends to demonstrate the existence of decentralized sources of judicial authority, which may be difficult to overcome by rules of general international law, but rather by rules of those special authorities which per se may be seen as a cause of fragmentation. While these cases do not demonstrate so much normative conflicts inherent in the problem of fragmentation, they do demonstrate the conflict of law-making authorities and jurisdiction in international law. 
Др Сања В. Ђајић, редовни йрофесор

Универзииетеи у Новом Саду

Правни факулиетеи у Новом Саду

S.Djajic@pf.uns.ac.rs

\section{Случај Ахмеа - пример тумачења међународних уговора, сукоба међународних судова и фрагментације међународног права}

Сажейик: У раду ауйорка анализира УНЦИТРАЛ арбийражне одлуке у инвестииционом сиору Ахмеа йротиив Словачке и одлуку Суда йравде ЕУ о саг̄ласносиии одредбе о рещавағу инвестииционих сйорова између инвесииийора и државе домаћина у двосиираном инвесиииционом сйоразуму закљученом између држава чланица ЕУ у йредмет̄у Ахмеа йройив Словачке. Суд иравде ЕУ уйврдио је несаг̆ласности ове одредбе са иравом ЕУ щйио може

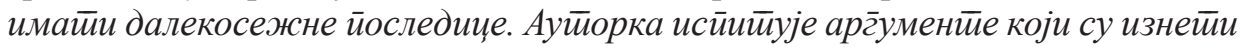
у овим одлукама из иерсиекиииве фраг̄менйачије међународног̄ иррава, йач-

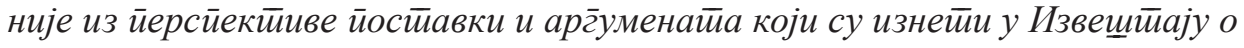
фрагіменииачији међународног йрава Комисије УН за међународно йраво.

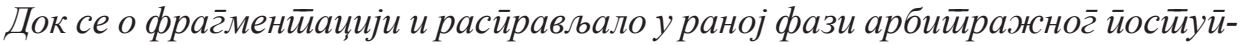
ка ова расиррава се касније изгуубила и фрагіментиачија као йаква није ни йоменуйа у одлуии Суда йравде ЕУ. Узрок различийих и суйройних одлука о односу одредби о решаваюу сйорова у двостираном инвестииционом сйоразуму и йрава ЕУ није йоследица стиварног̄ нормайивног̄ сукоба већ вище је йоследица чињенице да су о овом йитиағу одлучивали различитии судови.

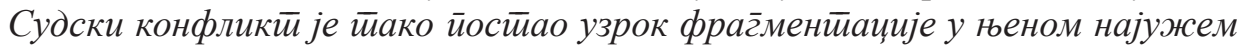
значењу када држава није у могуућностии да истиовремено исииуни обавезе из различитиих међународних уг̄овора.

Кључне речи: Ахмеа, фраг̄менйаиија, йумачење међународних уг̄овора, инвесиичииона арбииража.

Датум пријема рада: 01.10.2018. 